\title{
The occurrence of antibiotic resistance genes in tap water - a review
}

\author{
Agata Siedlecka ${ }^{1, *}$ \\ ${ }^{1}$ Wrocław University of Science and Technology, Faculty of Environmental Engineering, \\ Wyb. Wyspiańskiego 27, 50-370 Wrocław, Poland
}

\begin{abstract}
The study presents a review of the occurrence of genetic determinants of antibiotic resistance in tap water. The aim of this study was also to compare the applied methods for antibiotic resistance genes (ARGs) investigations in tap water. As the concentration of ARGs in treated, drinking water is expected to be very low and may cause problems in a standard isolation procedure, the special emphasis is placed on the applied procedures of DNA extraction and their efficiency. The study presents the first attempts to obtain DNA directly from tap water. Further efforts must be put to determine the final amount of obtained DNA and the presence of chosen ARGs among the molecules.
\end{abstract}

\section{Introduction}

The phenomenon of antibiotic resistance of bacteria is an emerging threat all over the world [1-4]. Nowadays, due to the high availability of antibiotics, the overuse of drugs is inevitable both in developed and developing countries. The increasing prevalence of antibiotic-resistant bacteria (ARB) is the obvious result of the situation [5-10]. As the prokaryotic genomes could be regarded as the molecules of high plasticity, their rapid adaptation to the new environmental conditions, i.e. presence of antibiotic agents, is expected $[6,9]$. This phenomenon is explained, among others, by the association of class 1 integrons to gene cassettes containing antibiotic resistance genes (ARGs). Therefore, investigations of ARGs are frequently supplemented by the intI gene research [11-13]. As ARB could cause incurable infections, the constant monitoring of their prevalence should be implemented in all environmental components, including wastewaters, soil, air, and waters [6]. Resistant bacteria, if present in wastewaters, could reach the catchment of a drinking water treatment plant with purified, but poorly disinfected wastewaters and then enter the water supply systems, in the case of insufficient water treatment processes $[13,14]$.

Although the major part of bacteria, including resistant strains, is retained in water treatment plants, the ARGs can enter a water supply system, because the dimensions of genes (which are indeed small DNA fragments) allow them to omit most of the treatment processes, including membrane units [15-17]. Moreover, disinfection processes could cause the lysis of bacterial cells in some circumstances, leading to the release of free DNA

*Corresponding author: agata.siedlecka@pwr.edu.pl 
molecules, which could contain the ARGs [9]. Drinking water treatment plants with biological activated carbon [18] or biological treatment tanks [19] may even increase normalized copy numbers of ARGs. To deactivate genes, the disinfectant must reach cell DNA in quantity not altered by previous contacts with other cell structures [9].

There are two major ways of spreading resistance among the bacteria: vertical gene transfer (in the process of proliferation) and horizontal gene transfer, i.e. conjugation, transformation, and transduction, promoted by mobile genetic elements (MGEs) [20, 21]. All of them contribute to the prevalence of the antibiotic resistance. However, the transformation is the most important, as in consequence of contact with ARGs, initially pathogenic, but susceptible (curable) strains may become pathogenic and resistant $[6,16]$. From this point of view, these genes could be regarded as the new contaminants $[9,22]$ and should be mandatorily monitored and suppressed.

In view of the fact, that drinking water is one of the main sources of potable water, its highest quality should be provided regardless of other factors. This means that the occurrence of ARGs should be investigated in water supply systems, as the intake of potable water containing these genes could lead to the transfer of resistance to human pathogenic strains [23-27]. Figueira et al. claimed that Enterobacteriaceae are 'vehicles' of resistance in drinking water [28]. The ability to transfer ARGs via conjugation by E. coli isolated from tap water was confirmed also by other studies [29, 30].

Moreover, most of the bacteria dwelling in tap water cannot be cultivated in laboratory conditions and remains undetectable. That may lead to underestimation of the problem [31]. Furthermore, the routinely applied method for detection of ARB, i.e. Kirby-Bauer discdiffusion method, is dedicated to human or animal pathogens, which present diverse optimum condition (temperature $35^{\circ} \mathrm{C}$ and rich nutrient medium like Mueller-Hinton agar) [32] than autochthonous tap water microorganism (which are psychrophilic and accustomed to habitats poor in nutrients) $[33,34]$. Therefore, the other way to investigate the antibiotic resistance phenomenon is needed and the detection of ARGs seems to be an appropriate solution.

\section{Investigations of ARGs in tap water}

In investigations of ARGs in tap water distribution systems, two main, different approaches may be distinguished:

-the isolation of ARB, identification of pure strains and determining the ARGs presence in isolates

-the metagenomic approach, which demands to obtain all DNA present in a water sample, including microorganisms' genomes and free DNA, to amplify or sequence the DNA and to apply bioinformatics analyses.

Regarding the human pathogenic or opportunistic pathogenic ARB in tap water, the first approach may be considered as sufficient, if appropriate laboratory conditions would be provided during the cultivation of bacteria. Nevertheless, the second approach may include the identification of all microorganisms to species, genes in the request and their amounts and, most importantly, does not demand the cultivation of bacteria in laboratory conditions, what in fact almost always leads to omitting many unculturable or non-viable species [35]. Moreover, the presence of free DNA, released from bacterial cells due to various processes, could be regarded as a dangerous contaminant itself [22], serving as a transferable element in the phenomenon of transformation (i.e. uptake and incorporation of DNA in a cell). From that point of view, not ARB, but simply ARGs present in tap water are the real threat factors.

In fact, the first approach is more common in literature. To date, there is a plethora of data concerning the presence of ARB in tap water [36, 37], but due to the development of 
molecular biology, insight into ARGs, omitting the cultivation of ARB, becomes a trend $[27,38]$.

\section{ARGs occurring in ARB and DNA isolated from tap water - a review}

Techniques commonly used for ARGs investigations include conventional PCR and its modifications, which allow to detect desired sets of genes and quantitative PCR (qPCR), i.e. real-time PCR, which allows to determine the copy number of selected genes. The PCR conditions, sequences of primers and additional information necessary to perform the research are often presented in literature (or in supplementary data). Newly discovered ARGs are constantly deposited in databases, as GenBank, for instance (https://www.ncbi.nlm.nih.gov/genbank/).

Another method for specific genes screening is a microarray with oligonucleotide probes. It could be used in search for virulence genes [39] as well as resistance genes $[40,41]$. Although 99\% correlation between PCR and microarray approaches was provided [40], the latter seems to be less common in the literature concerning ARGs. Furthermore, Henriques et al. applied also DGGE analysis to determine the molecular diversities of obtained bla PCR amplicons [42].

Together with ARGs, MGEs searching is often implemented, as this approach may indicate the prevalence and distribution of genes among the microorganisms [4, 27]. Predominantly, the MGEs investigations are focused on the intI gene encoding the class 1 integronase $[11,13]$.

The most frequently investigated ARGs are: bla genes encoding resistance to $\beta$-lactams (including the ESBL phenomenon), ampC genes encoding resistance to ampicillin, tet genes encoding resistance to tetracyclines, sul genes encoding resistance to sulphonamides, erm genes encoding resistance to erythromycin, cat and $\mathrm{cmr}$ genes encoding resistance to chloramphenicol, qnr genes encoding resistance to quinolones, among others $[14,16,43]$.

The search for ARGs began with screening the hospital, virulent, pathogenic isolates. For instance, the presence of various bla genes in Enterobacteriaceae strains isolated from hospital patients, including members of the blaCTX-M, blaSHV, and blaTEM families, was confirmed in many studies [7, 43-45]. The findings of Adesoji et al. indicated, that not only enteric, but also environmental strains carry bla genes [46], but this phenomenon is often neglected, as the environmental strains are perceived as harmless. Genes encoding $\beta$ lactamases and integrons were detected also in Gram-negative bacteria isolated from estuary [47]. Nevertheless, the occurrence of ARGs in tap water isolates and tap water itself became a fact.

Among 164 multidrug-resistant isolates from raw, treated, and municipal tap water in Nigeria, 61 were carrying bla genes. The most common gene family was blaTEM, present in 50 out of 61 PCR-positive isolates, which consisted mainly of Klebsiella spp. and Proteus spp. strains (18.03\% and $14.75 \%$ of the investigated isolates, respectively). However, the authors admitted that some phenotypically ESBL strains did not exhibit bla genes in PCR assays [46]. This fact may lead to the conclusion that there are still undiscovered genes conferring resistance to antibiotics or that the mechanisms of resistance are related with different mechanisms, encoded by other genes, as, for example, efflux pumps.

Khan et al. detected sull and sul2 genes in isolates from tap water samples, but these genes were never found together in the same strain. Moreover, the sull gene and the intI gene were not always present in the same strains, indicating that the sull gene could be associated with other MGEs or with bacterial chromosome. The authors were not able to 
confirm the presence of qac genes (encoding disinfectant resistance) in any of investigated strains [21].

In quantitative studies of ARGs, their abundance is often normalized to eubacterial $16 \mathrm{~S}$ rRNA present in the sample [38, 48]. Samples of DNA extracted from filtrated, disinfected and tap water were investigated in terms of ARGs presence and the effect of chlorination on their occurrence by Shi et al. The blaTEM-1, tetA, tetG, sulI, ermA and ermB genes were present in every sample, while $a m p C$ was found only in disinfected and tap water samples, indicating the promotion phenomenon of water treatment and distribution processes on these ARGs. The other gene, aphA2 (encoding resistance to aminoglycoside), seemed to disappear in tap water and three genes: tetB, tet $C$ and $\operatorname{drfA17}$ (encoding resistance to trimethoprim) remained undetected in each sample [38]. Results of qPCR showed that from eight ARGs taken into consideration in the study of Shi et al., the abundance of seven was increased after the chlorination unit. However, distribution of treated water decreased abundances of all eight ARGs. Interestingly, ARGs present in filtrated, disinfected and tap water could encode 9, 11 and 5 types of antibiotic-resistant proteins, respectively. Moreover, the class 1 integronase gene dominated the MGEs in each water sample, and the trend of the presence of integrons was similar to that of ARGs [38].

Studies of Shi et al. and $\mathrm{Xi}$ et al. demonstrated that the chlorination process reduced the abundance of the sull gene, but in the same time increases the richness of other genes $[38,48]$. Other treatment units also may influence ARGs quantity and diversity in drinking water $[18,19]$.

In the study of $\mathrm{Xi}$ et al., the copy number of majority of tested ARGs (cat, cmr, blaTEM, sulI, sulII) normalized to the copy number of 16S rRNA genes were higher in tap water samples than in treated water; the exception was the blaSHV gene (no significant difference observed) and the tet $O$ and tet $W$ genes, detected only in source water. Some samples demonstrated correlations between ARB and ARGs occurrences, i.e. phenotype resistance profiles corresponded with detected genes encoding resistance to insufficient antibiotics, though there was no significant correlation between ARGs and the total number of bacteria, nor 16S rRNA quantity [48].

Vaz-Moreira et al. detected the intIl, blaTEM and sull genes at copy numbers normalized to water volume. From 11 tested taps, intIl was quantified in 2 taps at all sampling dates, while blaTEM and sull were detected in all, but quantified in 9 and 2 taps, respectively, without temporal recurrence in both cases. The qnrS gene was not detected in any sample. Low quantities of intI1 and sull were attributed to the phenomenon of hiding these genes carriers by complex microbiota of tap water [49]. Nevertheless, the quinolone resistance genes were detected in Aeromonas spp. from tap water samples [50].

The increase of ARGs in drinking water distribution systems was confirmed in other studies. The amount of ARGs in tap water was from 6.4 to 109.2-fold higher than in treated water, produced in the water treatment plant in Hangzhou (China). The positive correlation between ARGs and MGEs in water distribution system was also confirmed. As highthroughput qPCR was applied in the study, the total number of 285 genes were searched. As a result, from 112 to 122 genes were found in tap water samples, depicting the diversity of ARGs in this medium [17]. The elevated level of ARGs in tap water, in comparison to treated water, was confirmed also by Zhang et al. [51].

\section{Extraction of DNA from ARB and tap water samples}

In every research approach, the most crucial step is the collection of samples. The applied procedures may affect all the subsequently obtained results. In the case of molecular biology investigations, the most essential stage is the extraction of DNA [52, 53]. 
DNA may be extracted from microorganisms in many ways, including the employment of commercial kits and other physical-chemical methods. Khan et al. extracted DNA by mixing strains with PBS, freezing and thawing the suspension at $-80^{\circ} \mathrm{C}$ and $70^{\circ} \mathrm{C}$, respectively, and centrifugation [21]. The simplest, but efficient approach was made by Osińska et al., as loopfuls of bacterial colonies were suspended in sterile water, heated at $95^{\circ} \mathrm{C}$ for $10 \mathrm{~min}$ and centrifuged $\left(5000 \mathrm{rpm}, 5 \mathrm{~min}, 4^{\circ} \mathrm{C}\right)[54]$.

Hwang et al. compared five methods of DNA extraction, including two commercial kits (dedicated for soil samples) and three classical phenol/chloroform procedures on monocultures of bacteria belonging to different genera (representatives of strains characterized by various cell wall properties). The authors used three approaches to determine DNA extract quality, quantity and purity: spectrophotometric NanoDrop technology, fluorescent-based quantitation Q-bit Quantitation Platform and agarose $(0.8 \%)$ gel electrophoresis using a DNA/HindIII fragment ladder. The applied methods revealed significant differences in obtained DNA amounts, reflected in bacterial diversity, but the DNA purity was sufficient in every approach. In general, the DNA obtained by commercial kits was pure enough to perform PCR assay (the minimum A260/A280 ratios was 1.40) and solutions obtained by phenol/chloroform methods required further purification steps in some cases, what could hinder PCR investigations [55]. The alternative solution was implemented by Zhang et al., who combined the application of the commercial kit with further phenol-ethanol methods [51].

As mentioned above, the extraction of DNA from bacterial colonies obtained from tap water and cultivated in laboratory conditions, even if rich in ARGs, may lead to the neglecting of the majority of microorganisms dwelling in tap water pipelines, thereby the metagenomic approach is likely to be an alternative. Nevertheless, DNA obtained from environmental samples may be contaminated with many PCR inhibitors. In the case of tap water, these inhibitors may be humic substances and corrosion, for example, which interfere with the DNA extraction process, altering the PCR results in consequence $[55,56]$. Nevertheless, Henriques et al. successfully purified freshwater samples on $5 \mu \mathrm{m}$ membranes, then concentrated microorganisms on $0.2 \mu \mathrm{m}$ pore-size filters, washed them in TE buffer, centrifuged (15 $200 \mathrm{~g}, 10 \mathrm{~min}$ ) and further processed by two commercial kits [42]. In a need for adequate DNA extraction from environmental samples, Bag et al. proposed THSTI method using enzymes, buffers, glass and zirconia beads, among others [52].

\subsection{Extraction of DNA directly from tap water - a preliminary research}

The aim of this preliminary research was to determine the minimal volume of tap water required to obtain a sufficient amount of DNA using commercial kits. The assumption was made, that the established volume needs to be useful in further comparative research, i.e. should not exceed $5 \mathrm{~L}$ of tap water, as larger volumes would be inappropriate in laboratory processing.

DNA was extracted simultaneously from $1 \mathrm{~L}, 3 \mathrm{~L}$ and $5 \mathrm{~L}$ of tap water. The output volume of tap water (collected from the same tap, according to PN-EN ISO 19458:2007 procedure) was filtrated in sterile conditions on $0.2 \mu \mathrm{m}$ membranes (Whatman). Afterwards, the membranes were shaken with 1xPBS buffer for $3 \mathrm{~h}$ at room temperature (200 rpm), then centrifuged respectively (9 $000 \mathrm{rpm}, 15 \mathrm{~min})$. Obtained pellet was subjected to DNA isolation by kits, according to with manufacturers' instructions. Unfortunately, the amount of obtained pellet in this approach was evidently too small to obtain sufficient concentration of DNA, even in $5 \mathrm{~L}$ sample. The obtained concentrations were insufficient to perform further research. Therefore, another approach and altered procedure must be applied. The small amount of pellet may be explained by the chosen 
sampling procedure, as in this study tap water was taken after flushing [PN-EN ISO 19458:2007].

As the issue in question was simply the output volume, not the exact diversity of nucleic acids, the extraction tool of choice was the commercial kit dedicated to Gram-negative bacteria, Genomic Mini (A\&A, Poland). According to the literature review, the volumes of fresh water and tap water used in DNA extraction procedures varied widely: from $15 \mathrm{~L}$ [49], through 10 $\div 15 \mathrm{~L}$ depending on the sample contamination and possible clogging of membrane [51], $4 \mathrm{~L}$ [57], $2 \div 1 \mathrm{~L}$ [58-60], $1.5 \mathrm{~L}$ [61] to $500 \mathrm{ml}$ [14] or $450 \mathrm{~mL}$ [42], depending on the sample origin. However, drinking water samples obtained by other researchers could have been affected by the biofilm dwelling in the taps. The volume collected in the study of Shi et al. was even $2000 \mathrm{~L}$, but using a different approach for the other objective [38]. In studies applying qPCR analyses, higher amounts of extracted DNA are required to provide the number of copy above the limit of quantification. In this study, the assumption was made, that the required DNA concentration is $20 \mathrm{ng} / \mu \mathrm{L}$ and the purity A260/280 $=1.8 \div 2.0$, what should be the sufficient parameters for further PCR investigations.

\section{CONSIDERED SOLUTIONS}

As it is known, the quality of tap water is inseparably correlated with water treatment processes. Technologies presently applied in water treatment plants do not provide the sufficient ARGs removing levels $[11,16,51,57]$. The proposed improvements may be the increase in dosages of chlorine and the intensity of UV irradiation or sequential UV/chlorination [9], but these solutions generate high costs. Among proposed technologies are also: Fenton and ozone oxidation, photocatalytic processes, biodegradation and nanoparticles (the last, though applied in medical research, seems to enhance the conjugative transfer of ARGs among bacteria in terms of water treatment) [9]. Besides the monitoring of ARB and ARGs, the analyses of antibiotics and drugs concentrations in wastewaters, freshwater, and tap water should be implemented, as these agents are probably responsible for resistance promotion [62-64]. According to Schwartz et al., the exposure of susceptible and resistant Pseudomonas aeruginosa strains to wastewater and tap water did not affect the expression of the intrinsic ARGs and MGEs [65], so the medium itself is not the main factor of the prevalence of resistance.

The significant issue in ARB and ARGs research is the discrepancy between phenotype and genotype [38] of bacteria dwelling in tap water. This hindrance may be overcome with the application of newly designed technologies for high-throughput sequencing and bioinformatics investigations of obtained sequences. The increasingly used in environmental microbiology studies Next Generation Sequencing (NGS) approach becomes more available and allows to gain seemingly more information of tested sample [66-68]. However, as indicated in this study, the successful implementation of NGS in tap water samples research requires proven, reliable and reproductive procedures of highefficiency DNA extraction from this medium. This step needs to be broken down and adapted to routine laboratory practice in the case of ARGs monitoring in tap water samples.

\section{References}

1. A. Rodríguez-Rojas, J. Rodríguez-Beltrán, A. Couce and J. Blázquez, Int. J. Med. Microbiol., 303, 293-297 (2013)

2. C.L. Ventola, P.T., 40(4), 277-283 (2015) 
3. M.Frieri, K. Kumar and A.Boutinc, Journal of Infection and Public Health, 10, 369378 (2017)

4. A. MacGowan and E. Macnaughton, MEDICINE, 45(10), 622-628

5. D.M. Fernando, H.M. Tun, J. Poole, R. Patidar, R. Li, R. Mi, G.E.A. Amarawansha, W.G.D. Fernando, E. Khafipour, A. Farenhorst and A. Kumar, Appl. Environ. Microbiol., 82(15), 4767-4775 (2016)

6. J.L. Martinez, Science, 321(5887), 365-367 (2008)

7. A. Ostholm-Balkhed, M. Tarnberg, M. Nilsson, L.E. Nilsson, H. Hakan, A. Hallgren, J. Antimicrob. Chemother., 68, 2144-2153 (2013)

8. WHO, Global Report on Surveillance (2014)

9. V.K. Sharma, N. Johnson, L. Cizmas, T.J. McDonald, K. Hyunook, Chemosphere, 150, 702-714 (2016)

10. L.Price, J. MacDonald, L. Melone, T. Howe, P. Flowers, K. Currie, E. Curran, V. Ness, D. Waddell, S. Manoukian, A. McFarland, C. Kilpatrick, J. Storr, A. Twyman, B. Allegranzi and J. Reilly, Lancet Inf. Dis., doi: 10.1016/S1473-3099(17)30479-6 (2017)

11. A. Farkas., A. Butiuc-Keul, D. Ciatarâş, C. Neamţu, C. Crăciunaş, D. Podar and M. Drăgan-Bularda, Sci. Total Environ., 443, 932-938 (2013)

12. S. Jia, P. Shi, Q. Hu, B. Li, T. Zhang and X.-X. Zhang, Environ. Sci. Technol., 49, 12271-12279 (2015)

13. A. Di Cesare, E.M. Eckert, S. D'Urso, R. Bertoni, D.C. Gillan, R. Wattiez, G. Corno, Water Res., 94, 208-214 (2016)

14. H.-C. Su, Y.-S. Liu, C.-G. Pan, J. Chen, L.-Y. He and G.-G. Ying, Sci. Total Environ., 616-617, 453-461 (2018)

15. M. Kabsch-Korbutowicz, K. Majweska-Nowak, Membrane separation processes in environmental protection (Wrocław University of Science and Technology, Wrocław, 2011)

16. S. Bergeron, R. Boopathy, R. Nathaniel, A. Corbin, G. LaFleur, Int. Biodeterior. Biodegradation, 102, 370-374, (2015)

17. L. Xu, W. Ouyang, Y. Qian, C. Su, J. Su., H. Chen, Environ. Pollut., 213, 119-126

18. J. Zheng, T. Chen and H. Chen, Sci. Total Environ., 612, 1-8 (2018)

19. X.Guo, J. Li, F. Yang, J. Yang and D.Yin, Sci. Total Environ., 493, 626-631 (2014)

20. Z. Markiewicz, Z.A. Kwiatkowski, Bakterie, antybiotyki, lekooporność (Wydawnictwo Naukowe PWN, Warszawa, 2008)

21. S. Khan, C.W. Knapp, T.K. Beattie, Environmental Processes, 3, 541-552 (2016)

22. J.M. Philip, U.K. Aravind and C.T. Aravindakumar, Chemosphere, 190, 307-326 (2018)

23. F. Baquero, J.L. Martinez and R. Canto, Curr. Opin. Biotechnol., 19, 260-265 (2008)

24. R. Tao., G.-G. Ying, H.-C. Su, H.-W. Zhou, J.P.S. Sidhu, Environ. Pollut., 158, 2101 2109 (2010)

25. A. Pruden, Environ. Sci. Technol., 48(1), 5-14 (2014)

26. S. Vincenti, G. Quaranta, C. De Meo, S. Bruno, M.G. Ficarra, S. Carovillano, W. Ricciardi and P. Laurenti, Sci. Total Environ., 499, 47-54 (2014)

27. J.L. Balcázar1, J. Subirats and C.M. Borrego, Front. Microbiol, 6(1216), 1-10 (2015)

28. V. Figueira, I. Vaz-Moreira, M. Silva, M.M. Celia, Water Res., 45, 5599-5611 (2011)

29. S.K. Walia, A. Kaiser, M. Parkash and G.R. Chaudhry, J. Environ. Sci. Health, 39(3), 6501-662 (2004)

30. B.L. Coleman, M.I. Salvadori, A.J. McGeer, K.A. Sibley, N.F. Neumann, S.J. Bondy, I.A. Gutmanis, S.A. McEwen, M. Lavoie, D. Strong, I. Johnson, F.B. Jamieson, M. Louie, ARO Water Study Group, Epidemiol. Infect., 140, 633-642 (2012)

31. I. Vaz-Moreira, C. Egas, O.C. Nunes, C.M. Manaia, FEMS Microbiol. Ecol. 83, 361374 (2013) 
32. R. Schwalbe, L. Steele-Moore, A.C. Goodwin (ed.), Antimicrobial Susceptibility Testing Protocols (CRC Press, Boca Raton, 2007)

33. T. Traczewska, M. Sitarska, I. Biedroń, Ekologiczne i techniczne aspekty powstawanie biofilmu $w$ wodzie (Wrocław University of Science and Technology, Wrocław, 2014)

34. A. Siedlecka and K. Piekarska, 9th Conference on Interdisciplinary Problems in Environmental Protection and Engineering EKO-DOK 2017, E3S Web of Conferences, 17 (2017)

35. S.A. Waller, A.I. Packman and M. Hausnerc, J. Microbiol. Methods, 144, 8-21 (2018)

36. C. Narciso-da-Rocha, I. Vaz-Moreira, L. Svensson-Stadler E.R.B. Moore and C.M. Manaia, Appl. Microbiol. Biotechnol., 97, 329-340 (2013)

37. C. Narciso-da-Rocha, I. Vaz-Moreira, C.M. Manaia, Sci. Total Environ. 466-467, 127-135 (2014)

38. P. Shi, S. Jia, X.-X. Zhang, T. Zhang, S. Cheng, A. Li, Water Res., 47, 111-120 (2013)

39. M.F. Anjum, M. Mafura, P. Slickers, K. Ballmer, P. Kuhnert, M.J. Woodward, R. Ehricht, Appl. Environ. Microbiol., 73(17), 5692-5697 (2007)

40. M. Batchelor, K.L. Hopkins, E. Liebana, P. Slickers, R. Ehricht, M. Mafura, F. Aarestrup, D. Mevius, F.A. Clifton-Hadley, M.J. Woodward, R.H. Davies, E.J. Threlfall and M.F. Anjum, Int. J. Antimicrob. Agents, 31, 440-451 (2008)

41. J.G. Frye, R.L. Lindsey, G. Rondeau, S. Porwollik, F. Long, M. McClelland, C.R. Jackson, M.D. Englen, R.J. Meinersmann, M.E. Berrang, J.A. Davis, J.B. Barrett, J.B. Turpin, S.N. Thitaram and P.J. Fedorka-Cray, Microb. Drug Resist., 16(1), 9-19 (2010)

42. I.S. Henriques, A. Moura, A. Alves, M.J. Saavedra, A. Correia, FEMS Microbiol. Ecol., 56, 418-429 (2006)

43. G. Wu, M.J. Day, M.T. Mafura, J. Nunez-Garcia, J.J. Fenner, M. Sharma, A. van Essen-Zandbergen, I. Rodríguez, C. Dierik, K. Kadlec, A.-K. Schink, J. Wain, R. Helmuth, B. Guerra, S. Schwarz, J. Threlfall, M.J. Woodward, N. Woodford, N. Coldham and D. Mevius, PLoS One, 8(9), 1-10 (2013)

44. F. Randrianirina, S. Vedy, D. Rakotovao, C.-E. Ramarokoto, H. Ratsitohaina, J.F. Carod, E. Ratsima, M. Morillon, A. Talarmin, J. Hosp. Infect., 72, 23-29 (2009)

45. D. Ojdana, P. Sacha, P. Wieczorek, S. Czaban, A. Michalska, J. Jaworowska, A. Jurczak, B. Poniatowski, E. Tryniszewska, International Journal of Antibiotics, 1-8 (2014) 46. A.T. Adesoji and A.A. Ogunjobi, Biomed. Res. Int., http://dx.doi.org/10.1155/2016/7149295, 1-9 (2016)

47. I.S. Henriques, F. Fonesca, A. Alves, M.J. Saavedra, A. Correia, Res. Microbiol., 157, 938-947 (2016)

48. C. Xi, Y. Zhang, C.F. Marrs, W. Ye, C. Simon, B. Foxman, J. Nriagu, Appl. Environ. Microbiol., 75(17), 5714-5718 (2009)

49. I. Vaz-Moreira, O.C. Nunes, C.M. Manaia, Sci. Total Environ., 586, 1141-1149 (2017)

50. V. Figueira, E.A. Serra, I. Vaz-Moreira, T.R.S. Brandâo, C.M. Manaia, J. Water Health, 10.1, 1-10 (2012)

51. S. Zhang, W. Lin, X. Yu, FEMS Microbiol. Ecol., 92(5), 1-9 (2016)

52. S. Bag, B.Saha, O. Mehta, D.Anbumani, Naveen Kumar, M. Dayal, A. Pant, P. Kumar, S. Saxena, K.H. Allin, T. Hansen, M. Arumugam, H. Vestergaard, O. Pedersen, V. Pereira, P. Abraham, R. Tripathi, N. Wadhwa, S. Bhatnagar, V.G. Prakash, V. Radha, R.M. Anjana, V. Mohan, K. Takeda, T. Kurakawa, G.B. Nair and B. Das, Sci Rep, 6(26775), 1-9 (2016)

53. A. Felczykowska, A. Krajewska, S. Zielińska and J.M. Łoś, Acta Biochim. Pol., 62(1), 151-160 (2015) 
54. A. Osińska, E. Korzeniewska, M. Harnisz, S. Niestępski, Sci. Total Environ., 577, 367-375 (2017)

55. C. Hwang, F. Ling, G.L. Andersen, M.W. LeChevallier, W.-T. Liu, Microbes and Environ., 27(1), 9-18 (2012)

56. I.G. Wilson, Appl. Environ. Microbiol., 63(10), 3741-3751 (1997)

57. X. Bai, X. Ma, F. Xu, J. Li, H. Zhang, X. Xiao, Sci. Total Environ. 533, 24-31 (2015)

58. K. Lautenschlager, N. Boon, Y. Wang, T. Egli and F. Hammes, Water Res., 44, 48684877 (2010)

59. K. Lautenschlager, C. Hwang, W.-T. Liu, N. Boon, O. Koster, H. Vrouwenvelder, T. Egli and F. Hammes, Water Res., 47, 3015-3025 (2013)

60. E.I. Prest, J. El-Chakhtoura, F. Hammes, P.E. Saikaly, M.C.M. van Loosdrecht and J.S. Vrouwenvelder, Water Res., 63, 179-189 (2014)

61. E.P. Holinger, K.A. Ross, C.E. Robertson, M.J. Stevens, J. Kirk Harris and N.R. Pace, Water Res., 49, 225-235 (2014)

62. J. Fick, H. Soderstrom, R.H. Lindberg, C. Phan, M. Tysklind and D.G.J. Larsson, Environ. Toxicol. Chem., 28(12), 2522-2527 (2009)

63. Yiruhan, Q.-J. Wang, C.-H. Mo, Y.-W. Li, P. Gao, Y.-P. Tai, Y. Zhang, Z.-L. Ruan, J.-W. Xu, Environ. Pollut., 158, 2350-2358 (2010)

64. D.I. Andersson, D. Hughes, Drug Resist Update, 15, 162-172 (2012)

65. T. Schwartz, O. Armant, N. Bretschneider, A. Hahn, S. Kirchen, M. Seifert, A. Dötsch, Microb. Biotechnol., 8(1), 116-130 (2015)

66. B.F. Tan, C. Ng, J.P. Nshimyimana, L.L. Loh, K.Y.-H. Gin and J.R. Thompson, Front. Microbiol., 6(1027), 1-10 (2015)

67. C.R. Proctor and F. Hammes, Curr. Opin. Biotechnol., 33, 87-94 (2015)

68. R.P.A. Pereira, J. Peplies, I. Brettar and M.G. Höfle, BMC Microbiol., 17(79), 1-14 (2017) 